\title{
Proximate Analysis and Hydrolysis of Malted Millet (Panicum Miliaceum) Blended with Maize and Rice Flour
}

\author{
Umaru Ayuba Alfa \\ Dept of Chemistry, College Of Education, Gindiri \\ P.M.B, 01000, Gindiri, Plateau State Nigeria \\ Emmanuel Ishaya Genwa \\ Boys' Seconday School, Gindiri \\ P.M.B, 1001, Gindiri, Plateau State, Nigeria
}

\section{Doi:10.5901/ajis.2013.v2n12p13}

\begin{abstract}
The physico-chemical result of the analysis of proso millet (Panicum milliaceum) showed the optimum water uptake of the millet to be 96 hours, optimum malting time 96 hours, ash content $3.26 \pm 0.03$, moisture content $11.37 \%, \pm 0.33$, crude fat content $1.30 \% \pm 0.20$, crude protein content $13.87 \% \pm 0.5$, carbohydrate content $71.46 \% \pm 0.80$, reducing sugars $35.08 \% \pm 0.80$, hydrolysable sugars $54.29 \% \pm 0.70$ and fibre content $6.37 \% \pm 0.30$. the mineral composition of proso millet in $\mathrm{mg} / 100 \mathrm{~g}$ showed that the millet contains $K(2.14)$, Fe (1.04), $\mathrm{mg}(0.85)$, Ca (0.65), $\mathrm{Na}$ (0.17), Al (0.13), Mn (0.013), Zn (0.04), Pb (Lead) was not detected in the milled. Temperature and PH Shidies on the malted millet showed the optimum values to be $500 \mathrm{c}-600 \mathrm{c}$ and 5-6 respectively. The blending ratio of the gelatinized maize flour ground with the chaff with malted millet was found to be 50\%, while the blending ratio of gelatinized maize after removing the chaff with malted milled was determined to be $60 \%$. The blending ratio of the gelatinized rice flour with malted millet was also found to be $60 \%$. The decrease of about $10 \%$ in the value of reducing sugar production between the two maize flours could be due to the fact that, the unprocessed seeds have more lignified materials which could inhibit access to amylase during hydrolysis. The absence of heavy metal lead $(P b)$ and high carbohydrate content of proso millet indicates that it could be used in the brewing industry as an adjunct to barley.
\end{abstract}

\section{Introduction}

Proso millet (Panicum miliaceum) belongs to the family Gramineae, which is a large family of grasses with about 620 genera and 1,000 species dispersed in many parts of the world where plants can survive. Gramineae is economically the most important family of flowering plants; the grasses provide diet of most of the world population. This is the reason for the extensive studies of the chemical composition of cereals, optimum water uptake, optimum malting time and also the determination of whether the amylases of the malted cereals could be used to hydrolyse starches of other cereals such as maize flour before and after removing the chaff and also rice flour.

Maize (Zea mays) is one most important cereals in the world apart from wheat and rice. It also belongs to the family Gramineae. It is also an adjunct needed in the brewing industry as raw material for the production of starch and other beverages. It is ground into powdered form and made into porridge called Kpekple in Ghana, Kunu (Hausa) in Northern Nigeria. Bidia in Zaire, Sadza in Zimbabwe, puto in Zulu land. The meal obtained from maize is cooked with water to provide a thick meal called tuwo (Hausa) Northern Nigeria.

Rice (Oryza sativa) is the seed of the monocot plant. Rice is the most important grain with 
regard to human nutrition and caloric intake. It provides more than one fith $(1 / 5)$ of the calories consumed worldwide by humans. Rice is usually cooked by boiling and is eaten mostly with fish, vegetable or meat.

Raw rice may be ground into powder (flour) and converted into many uses including rice milk, rice wine etc.

Carbohydrates. Canbolydrates belong to the class of organic compounds having the general molecular formular of $\mathrm{CnH}_{2 \mathrm{n}} \mathrm{O}_{\mathrm{n}}$.

Starch, glucose, cellulose and glycogen all belong to this class of organic compounds. Starches are substances which constitute the major part of the human diet for almost half of the world population as swell as animals. Starch molecules are glucose polymers linked together by a 1 4 and a 16 glycoside bonds as opposed to the $\beta 14$ glycoside bonds for cellulose. Enzymes are capable of hydrohyzing starch usually to form oligosaccharides and other smaller units e.g disaccharides and monosaccharides. This is possible with a special type of enzymes called alpha amylase which is present in the saliva of human beings and can hydrolyse starch to maltose and glucose. Partial hydrolysis of starch usually produces Dextrin which is a mixture of D - glucose and branched oligosaccharide. Dextrin is often a component of infant diet because it is easily digestible starch granules are quite resistant to penetration to both water and hydrolytic enzymes due to the formation of intermolecular and intermolecular hydrogen bonds. However the hydrogen bonds can be weakened as the temperature of the suspension is raised. When this happens, water absorption becomes possible and the starch granules swell. This process is called gelatinization.

Malting:- The process of malting actually refers to all the charges that take place during the development of the seed into seedling in which water is absorbed by the seed through the micropyle, thus causing the entire seed to swell up. The cells of the cotyledon become active and turgid and begin to make use of the water to dissolve and digest the food solution stored in them. The solublised foods reserved are then transported to the growing plumule and radicle.

Malting also called germination is affected by a number of factors such as temperature, water, air, enzymes, and $\beta$ amylase provide an appropriate medum for the degradation of the starch inside the grain into simple sugars such as glucose and maltose. In addition to starch degradation, the reserved protein inside the seed is also degraded into appropriate mixture of polypeptide and amino acid by specific enzymes called protein degrading enzymes.

\section{Materials and Methods}

\subsection{Collection of samples and preparation for analysis}

The millet seeds (Panicum Miliaceum) were obtained from Kadamo in Jengre, Bassa Local Government Area of Plateau State. The feeds were winnowed to remove dust and pebbleds. The seeds were ground into powder and stored in a dessicator for the analysis, but maize seeds were divided into two, one part ground with the chaff and the other part ground after removing the chaff, while some millet seeds were kept aside for water uptake and malting quality analysis.

\subsection{Optimum water uptake determination}

$5.0 \mathrm{~g}$ of millet grains was weighed at room temperature $25^{\circ} \mathrm{C}-28^{\circ} \mathrm{C}$ and steeped in twelve (12) pre-weighed petri dishes for various hours from 12 hours to 144 hours. Each of the petri dishes was removed after pre-determined time interval of 12 hours and the water drained off and was allowed to dry at temperature of $25^{\circ} \mathrm{C}-28^{\circ} \mathrm{C}$ for exactly 2 hours. The sample was then re-weighed and the increase in weight was then expressed as the percentage water uptake of the millet grains. 


\subsection{Determination of optimum malting time}

$5.5 \mathrm{~g}$ millet grains were each placed into five different pre-weighed petri dishes containing filter paper inside them in order to keep the grains wet and were steeped at room temperature. The millet grains were allowed to germinate (i.e green malting) for various number of hours by changing the water at time intervals of 16hours. Each of the samples was milled after a time interval of 24 hours, 48 hours, 72 hours, 96 hours and 120 hours. Each of the milled samples was transferred into $100 \mathrm{ml}$ standard volumetric flask and acetate buffer solution $\mathrm{P}^{\mathrm{H}} 5.5$ was added to each milled sample and hydrolysed at various temperatures of $30^{\circ} \mathrm{C}, 50^{\circ} \mathrm{C}, 60^{\circ} \mathrm{C}, 70^{\circ} \mathrm{C}$ and $80^{\circ} \mathrm{C}$ respectively for 2 hours using thermostat water bath. The hydrolysed sample was then centrifuged and assayed for reducing sugar by Nelson Method.

\subsection{Determination of ash content}

About $3.0 \mathrm{~g}, 4.0 \mathrm{~g}$ and $5.0 \mathrm{~g}$ of ground moisture free millet samples were placed inside pre-weighed porcelain crucibles. The crucibles were then placed in a muffle furnace and the temperature maintained at $600^{\circ} \mathrm{C}$ for about 8hours. The crucibles were then removed and reweighed. The weight of the ash was expressed as the $\%$ ash content of the millet samples.

Table 1: Determination of Ash Content

\begin{tabular}{|c|c|c|c|c|c|c|c|}
\hline s/no & $\begin{array}{c}\text { weight of } \\
\text { sample (g) }\end{array}$ & $\begin{array}{c}\text { weight of empty } \\
\text { crucible }\end{array}$ & $\begin{array}{c}\text { weight of sample } \\
\text { and crucible }\end{array}$ & $\begin{array}{c}\text { weight before } \\
\text { ashing }\end{array}$ & $\begin{array}{c}\text { Weight after } \\
\text { ashing }\end{array}$ & $\begin{array}{c}\text { lost in } \\
\text { weight }\end{array}$ & $\begin{array}{c}\% \text { ash } \\
\text { content }\end{array}$ \\
\hline 1 & 3.00 & 18.4482 & 21.4482 & 21.4482 & $21.34 \%$ & 0.0986 & 3.2867 \\
\hline 2 & 4.00 & 19.5460 & 23.5460 & 23.5460 & 23.4168 & 0.1292 & 3.2300 \\
\hline 3 & 5.00 & 19.1512 & 24.1512 & 24.1512 & 23.9874 & 0.1638 & 3.2760 \\
\hline
\end{tabular}

$\%$ Ash Content $=3.26 \pm 0.03$

\subsection{Determination of moisture content}

$5.0 \mathrm{~g}, 6.0 \mathrm{~g}$ and $7.0 \mathrm{~g}$ of ground moisture free millet samples were weighed into 3 pre-weighed dry clean small size beakers $(50 \mathrm{ml})$ and were allowed to dry inside a hot air Gallen - kanp oven for about 24 hours maintained at a temperature of $105^{\circ} \mathrm{C}$. After drying, the samples were allowed to cool in dessicators for about 2 hours after which they were reweighed. The $\%$ loss in the weight was expressed as the moisture content of the millet.

Table 2: determination of moisture content

\begin{tabular}{|c|c|c|c|c|c|c|}
\hline S/No & $\begin{array}{c}\text { weight of } \\
\text { sample }(\mathrm{g})\end{array}$ & $\begin{array}{c}\text { weight of empty } \\
\text { beaker }\end{array}$ & $\begin{array}{c}\text { sample + beaker } \\
\text { (before) }\end{array}$ & $\begin{array}{c}\text { sample }+ \\
\text { beaker (after }\end{array}$ & $\begin{array}{c}\text { lost in } \\
\text { weight }\end{array}$ & $\begin{array}{c}\% \text { moisture } \\
\text { content }\end{array}$ \\
\hline 1 & 5.00 & 22.2043 & 27.2043 & 26.6492 & 0.5551 & 11.10 \\
\hline 2 & 6.00 & 20.3392 & 26.3392 & 25.6288 & 0.7104 & 11.84 \\
\hline 3 & 7.00 & 21.6546 & 28.6546 & 27.8724 & 0.7822 & 11.17 \\
\hline
\end{tabular}

\subsection{Determination of crude fat}

Ground moisture free millet samples of $8.0 \mathrm{~g}, 9.0 \mathrm{~g}$ and $10.0 \mathrm{~g}$ were weighed into 3 different pre weighed fat - free white cloths and wrapped separately. The wrapped samples were then weighed into 3 different fat - free thimbles. This was then soxhlet extracted using petroleum ether $\left(60^{\circ} \mathrm{C}\right.$ $80^{\circ} \mathrm{C}$ ) for 8 hours after which the thimbles were carefully removed and allowed to dry at room temperature. The thimbles and the samples inside were reweighed after drying. The difference in 
the weight was expressed as the percentage crude fat content of millet.

Table 3: Determination of crude fat

\begin{tabular}{|c|c|c|c|c|c|c|c|}
\hline S/No & $\begin{array}{c}\text { weight of } \\
\text { sample }(\mathrm{g})\end{array}$ & $\begin{array}{c}\text { weight of } \\
\text { white cloth }\end{array}$ & $\begin{array}{c}\text { weight of } \\
\text { thimble }\end{array}$ & $\begin{array}{c}\text { total weight before } \\
\text { extraction }\end{array}$ & $\begin{array}{c}\text { total weight after } \\
\text { extraction }\end{array}$ & $\begin{array}{c}\text { lost in } \\
\text { weight }\end{array}$ & $\begin{array}{c}\% \text { crude } \\
\text { fat }\end{array}$ \\
\hline 1 & 8.00 & 1.6724 & 9.8024 & 19.4748 & 19.3538 & 0.1210 & 1.513 \\
\hline 2 & 9.00 & 2.0748 & 11.0134 & 21.0882 & 21.9865 & 0.1017 & 1.130 \\
\hline 3 & 10.00 & 2.1698 & 12.1026 & 24.2724 & 24.1602 & 0.1122 & 1.122 \\
\hline
\end{tabular}

\subsection{Determination of crude protein and nitrogen}

$0.5 \mathrm{~g}$ of ground moisture free millet samples were weighed on different ashless filter papers wrapped together and quantitatively transferred into 3 different Kjeldahl digestion flasks labeled $A, B, C$ with the fourth flask labeled $D$, blank sample $0.2 \mathrm{~g}$ of the catalyst (mixture of anhydrous $\mathrm{Na}_{2}$ $\mathrm{SO} 4, \mathrm{CuSO}_{4}$ and $\mathrm{SeO}_{2}$ ) was added to each flask followed by $10 \mathrm{ml}$ of concentrated $\mathrm{H}_{2} \mathrm{SO}_{4}$ and few pieces of anti-bombing granules was added to each of the flask. The Kjeldahl flasks were heated gently at first. As the fumes ceased, the heating is increased and would continue for about 2-4 hours after which a clear solution is obtained. The solution was allowed to cool and diluted with distilled water with the flasks immersed inside the bath. The diluted solution was then transferred into a $100 \mathrm{ml}$ volumetric flask and made up to the mark for all the samples with distilled water.

Kjeldahl distillation apparatus (Markehan still) was assembled over a Bunsen burner and 10ml of the digested sample was transferred into the flask through the funnel connected by means of a spray bulb to the condenser. $20 \mathrm{ml}$ of $40 \% \mathrm{NaOH}$ was added to the flask containing the digested sample while the tip of the condenser was deeped into $20 \mathrm{ml}$ of $2 \%$ Boricacid containing few drops of the indicator (mixture of methylred and methylene blue indicators) was added. Ammonia released was passed through the condenser to the Boricacid which changed the colour from purple colour to green. The heating was stopped after about $75 \mathrm{ml}$ of the solution was collected. The solution was then titrated against $0.05 \mathrm{M} \mathrm{H}_{2} \mathrm{SO}_{4}$ untill the purple colour of the Boricacid reappeared. This is the end point. Percent protein was expressed according to the formula

$$
\begin{aligned}
& \% \mathrm{~N}_{2}=\frac{14\left(\mathrm{~T}_{\mathrm{s}}-\mathrm{T}_{\mathrm{b}}\right) \times \mathrm{M} \mathrm{X} 100 \times 2}{1000 \times 10 \times \text { weight of sample }} \\
& \text { Where } \mathrm{T}_{\mathrm{b}}=\text { volume of the standard acid of blank } \\
& \mathrm{Ts}=\text { Volume of the standard acid in the titration } \\
& \mathrm{M}=\text { Molarity of the } \mathrm{H}_{2} \mathrm{SO}_{4} \\
& 10=\text { Volume of the sample used } \\
& 100=\text { Dilution factor used } \\
& 14=\text { Atomic weight of Nitrogen. }
\end{aligned}
$$

Table 4: Determination of Crude protein

\begin{tabular}{|c|c|c|c|c|c|}
\hline S/No & weight of sample $(\mathrm{g})$ & Titre value of sample $\left(\mathrm{CM}^{3}\right)$ & volume of sample- volume of blank & $\% \mathrm{~N}_{2}$ & $\%$ protein \\
\hline 1 & sample 0.5027 & 1.20 & 0.83 & 2.13 & 14.25 \\
\hline 2 & sample 0.5027 & 1.13 & 0.76 & 2.12 & 13.26 \\
\hline 3 & sample 0.5027 & 1.17 & 0.80 & 2.23 & 13.93 \\
\hline
\end{tabular}

$\%$ Crude Nitrogen $=2.22 \pm 0.08$ Titre value $\%$

$\%$ Crude protein $=13.87 \pm 0.5$ Blank sample $=0.37$ 


\subsection{Preparation of standard curve for total carbohydrate using d (+) glucose}

$0.1802 \mathrm{~g}$ Vacuumdried $\mathrm{D}(+)$ glucose was weighed and quantitatively transferred into a $100 \mathrm{ml}$ volumetric flask and dissolved and made up to the mark with distilled water producing $0.01 \mathrm{M}$ glucose solution $(10 \mu \mathrm{m} / \mathrm{ml})$. From the solution $5 \mathrm{ml}$ were each pipetted and transferred into a $100 \mathrm{ml}$ standard volumetric flask and made up to the mark with distilled water, with the concentrations as $0.5 \mu \mathrm{m} / \mathrm{ml} .1 .0 \mu \mathrm{m} / \mathrm{ml}, 1.5 \mu \mathrm{m} / \mathrm{ml}, 2.0 \mu \mathrm{m} / \mathrm{ml}, 2.5 \mu \mathrm{m} / \mathrm{ml}, 3.0 \mu \mathrm{m} / \mathrm{ml}, 3.5 \mu \mathrm{m} / \mathrm{ml}$, $4.0 \mu \mathrm{m} / \mathrm{ml}, \mu \mathrm{m} / \mathrm{ml}, 4.5 \mu \mathrm{m} / \mathrm{ml}$ and $5.0 \mu \mathrm{m} / \mathrm{ml}$ respectively. To each of the above standards, $1 \mathrm{ml}$ was taken and placed in a test tube standing inside ice bath and $5 \mathrm{ml}$ of $\mathrm{L}$ - Cysteine, sulphuricacid was added in the ratio 1:5. The test tubes were then covered with aluminium foils and then heated inside boiling water for 3 minutes after which they were allowed to Cool to room temperature and the absorbance immediately taken at $420 \mathrm{~nm}$ using colorimeter. The reading of the absorbance was then plotted against the corresponding values of the sugar concentration.

Table 5: standard curve values of $D(+)$ glucose by $L$ - Cysteine sulphuricacid method .

\begin{tabular}{|c|c|c|c|}
\hline $\begin{array}{c}\text { No of test } \\
\text { tube }\end{array}$ & $\begin{array}{c}\text { Dilution of glucose and } \\
\text { dist. water }(\mathrm{ml})\end{array}$ & $\begin{array}{c}\text { Standard conc. Of sugar } \\
(\mu \mathrm{m} / \mathrm{ml})\end{array}$ & $\begin{array}{c}\text { Absorbance max 420 } \\
(\mathrm{nm})\end{array}$ \\
\hline 1 & $5 / 95$ & 0.50 & 0.08 \\
\hline 2 & $10 / 90$ & 1.00 & 0.16 \\
\hline 3 & $15 / 85$ & 1.50 & 0.24 \\
\hline 4 & $20 / 80$ & 2.00 & 0.32 \\
\hline 5 & $25 / 75$ & 2.50 & 0.40 \\
\hline 6 & $30 / 70$ & 3.00 & 0.48 \\
\hline 7 & $35 / 65$ & 3.50 & 0.56 \\
\hline 8 & $40 / 60$ & 4.00 & 0.64 \\
\hline 9 & $45 / 55$ & 4.50 & 0.72 \\
\hline 10 & $50 / 50$ & 5.00 & 0.80 \\
\hline
\end{tabular}

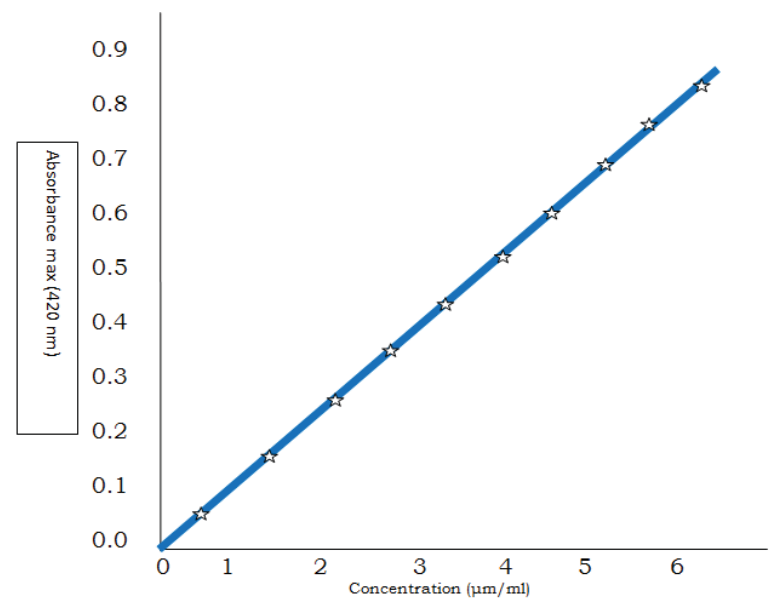

Fig 1: Total carbohydrate by L - Cysteine sulpuricacid method.

\subsection{Determination of mineral content}

$2.0 \mathrm{~g}$ each of the ground millet sample was weighed and placed into two different crucibles and ashed at temperature of $600^{\circ} \mathrm{C}$ for 8 hours. The crucibles were then removed after ashing and 
cooled in dessicators. The ash was quantitatively transferred into $150 \mathrm{ml}$ beakers. To the ashes in the beakers, $10 \mathrm{ml}$ of distilled water, $10 \mathrm{ml}$ of concentrated perchloricacid, $10 \mathrm{ml}$ of concentrated hydrochloricacid and $10 \mathrm{ml}$ of concentrated trioxonitrate $(\mathrm{v})$ acid were added. The beakers were covered and heated at a temperature of $120^{\circ} \mathrm{C}$ on a hot plate until the emmission of brown fumes stopped. The sides of the beakers were rinsed with dislilled water and then heated further to concentrae the solution to $5 \mathrm{ml}$. the beakers were then removed and cooled before adding $10 \mathrm{ml}$ of concentrated $\mathrm{HNO}_{3}$. To the solution, $5 \mathrm{ml}$ of distilled water was added and boiled for 5 minutes. The solutions were then filtered into $100 \mathrm{ml}$ standard volumetric flask and made up to the mark with distilled water. The solutions of the samples prepared were then used to determine the elements of interest using atomic absorption spectroscopy machine (AAS). The metals determined were; $\mathrm{Ca}$, $\mathrm{Fe}$, $\mathrm{Se}, \mathrm{Mg}, \mathrm{Ni}, \mathrm{Mn} . \mathrm{K}, \mathrm{Cd}, \mathrm{As}, \mathrm{Na}, \mathrm{Pb}, \mathrm{Cu}, \mathrm{Zn}, \mathrm{Al}$.

Table 6: Determination of mineral content

\begin{tabular}{|c|c|c|c|c|c|c|}
\hline S/NO & Element & \multicolumn{2}{|c|}{$\mathrm{Mg} / \mathrm{L} \mathrm{Mg} / 100 \mathrm{~g}$ Sample/ } & \multicolumn{2}{c|}{ dry weight } & Mean values \\
\hline & & $\mathrm{A}$ & $\mathrm{B}$ & $\mathrm{A}$ & $\mathrm{B}$ & \\
\hline 1 & $\mathrm{Al}$ & 65.39 & 66.55 & 0.1367 & 0.1212 & 0.1290 \\
\hline 2 & $\mathrm{As}$ & 13.25 & 14.85 & 0.0277 & 0.0271 & 0.0274 \\
\hline 3 & $\mathrm{Ca}$ & 331.0 & 335.0 & 0.6919 & 0.6102 & 0.6511 \\
\hline 4 & $\mathrm{Cd}$ & 0.321 & 0.291 & 0.0007 & 0.0005 & 0.0006 \\
\hline 5 & $\mathrm{Cr}$ & 5.501 & 5.551 & 0.0115 & 0.0101 & 0.0108 \\
\hline 6 & $\mathrm{Cu}$ & 15.59 & 15.81 & 0.0326 & 0.0288 & 0.0307 \\
\hline 7 & $\mathrm{Fe}$ & 535.9 & 537.5 & 1.1202 & 0.9681 & 1.0442 \\
\hline 8 & $\mathrm{~K}$ & 1113 & 1069 & 2.3265 & 1.9472 & 2.1369 \\
\hline 9 & $\mathrm{Mg}$ & 414.9 & 452.7 & 0.8668 & 0.8246 & 0.8457 \\
\hline 10 & $\mathrm{Mn}$ & 6.455 & 6.293 & 0.0135 & 0.0115 & 0.0125 \\
\hline 11 & $\mathrm{Na}$ & 87.73 & 90.89 & 0.1834 & 0.1656 & 0.1745 \\
\hline 12 & $\mathrm{Ni}$ & 0.132 & 0.146 & 0.0003 & 0.0003 & 0.0003 \\
\hline 13 & $\mathrm{~Pb}$ & $\mathrm{~N} . \mathrm{D}$ & $\mathrm{N} . \mathrm{D}$ & $\mathrm{N} . \mathrm{D}$ & $\mathrm{N} . \mathrm{D}$ & $\mathrm{N} . \mathrm{D}$ \\
\hline 14 & $\mathrm{Se}$ & 2.147 & 2.237 & 0.0045 & 0.0041 & 0.0043 \\
\hline 15 & $\mathrm{Zn}$ & 18.45 & 17.44 & 0.0386 & 0.0318 & 0.0352 \\
\hline
\end{tabular}

\subsection{Determination of optimum blending ratio of malted millet and rice flour}

Rice flour and malted millet were blended in the following ratio to make up $5 \mathrm{~g}$.

$0.5: 4.5,1: 4,1.5: 3.5,2: 3,2: 5,2.5,3: 2,3.5: 1.5,4: 1$,

The rice flour was gelatinized first in $100 \mathrm{ml}$ of $0.05 \mathrm{M}$ acetate buffer $\mathrm{P}^{\mathrm{H}} 5.5$ then cooled to a temperature of $50^{\circ} \mathrm{C}$ before adding the malted millet. The solutions were then allowed to hydrolyse at a temperature of $50^{\circ} \mathrm{C}$ for exactly 2 hours. Samples of the solutions were withdrawn, centrifuged and assayed for reducing sugar by Nelson method, max 520nm using a colorimeter.

Table 7: Determination of optimum blending ratio of malted millet and rice flour.

\begin{tabular}{|c|c|c|c|c|c|}
\hline S/NO & $\begin{array}{c}\text { Weight of rice } \\
\text { flour }(\mathrm{g})\end{array}$ & $\begin{array}{c}\text { Weight of malted } \\
\text { millet }(\mathrm{g})\end{array}$ & $\begin{array}{c}\text { Absorbance at max } \\
520 \mathrm{~nm}\end{array}$ & $\begin{array}{c}\text { Concentration } \\
\mathrm{mg} / \mathrm{ml}\end{array}$ & $\begin{array}{c}\% \text { hydrolyted } \\
\text { sugar }\end{array}$ \\
\hline 1 & 0.5 & 4.5 & 0.11 & 180 & 0.65 \\
\hline 2 & 1.0 & 4.0 & 0.14 & 240 & 0.84 \\
\hline 3 & 1.5 & 3.5 & 0.18 & 320 & 1.15 \\
\hline 4 & 2.0 & 3.0 & 0.24 & 440 & 1.59 \\
\hline 5 & 2.5 & 2.5 & 0.25 & 460 & 1.66 \\
\hline 6 & 3.0 & 2.0 & 0.25 & 460 & 1.66 \\
\hline 7 & 3.5 & 1.5 & 0.20 & 360 & 1.30 \\
\hline
\end{tabular}




\begin{tabular}{|l|l|l|l|l|l|}
\hline 8 & 4.0 & 1.0 & 0.16 & 280 & 1.01 \\
\hline 9 & 4.5 & 0.5 & 0.12 & 200 & 0.72 \\
\hline
\end{tabular}

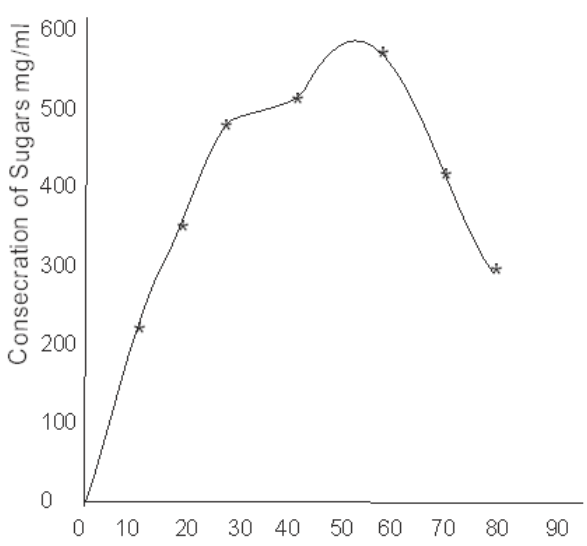

Fig. 2.

\subsection{Determination of optimum blending ration of malted millet and maize flour ground with the chaff (unprocessed)}

Maize flour ground with the chaff was blended with malted millet in the following ratios to make 5g. 0.5: 4.5, 1.0:4.0, 1.5:3.5, 2.0:3.0, 2.5:2.5, 3.0:2.0, 3.5:1.5, 4.0:1.0, 4.5:0.5.

The maize flour was gelatinized first in $100 \mathrm{ml}$ of $0.05 \mathrm{ml}$ acctate buffer $\mathrm{P}^{\mathrm{H}} 5.5$. It was cooled to a temperature of $50^{\circ} \mathrm{C}$ before the malted millet was added. The solution was hydrolysced at a temperature of $50^{\circ} \mathrm{c}$ using a thermostat water bath for about 2 hours. Samples were withdrawn, centrifuged and assayed for reducing sugars by Nelson method max $520 \mathrm{~nm}$ using a colorimeter.

Table 8: Determination of optimum blending ratio of malted millet and maize flour ground with chaff.

\begin{tabular}{|c|c|c|c|c|c|}
\hline S/No & $\begin{array}{c}\text { weight of maize } \\
\text { flour }(\mathrm{g})\end{array}$ & $\begin{array}{c}\text { weight of malted } \\
\text { millet }(\mathrm{g})\end{array}$ & $\begin{array}{c}\text { Absorbance } \\
(520 \mathrm{~nm})\end{array}$ & $\begin{array}{c}\text { concentration } \\
(\mathrm{Mg} / \mathrm{MI})\end{array}$ & $\begin{array}{c}\% \\
\text { hydrolyzed }\end{array}$ \\
\hline 1 & 0.5 & 4.5 & 0.08 & 120 & 0.43 \\
\hline 2 & 1.0 & 4.0 & 0.12 & 200 & 0.72 \\
\hline 3 & 1.5 & 3.5 & 0.17 & 300 & 1.08 \\
\hline 4 & 2.0 & 3.0 & 0.20 & 360 & 1.30 \\
\hline 5 & 2.5 & 2.5 & 0.22 & 400 & 1.44 \\
\hline 6 & 3.0 & 2.0 & 0.20 & 360 & 1.30 \\
\hline 7 & 3.5 & 1.5 & 0.17 & 300 & 1.08 \\
\hline 8 & 4.0 & 1.0 & 0.14 & 240 & 0.86 \\
\hline 9 & 4.5 & 0.5 & 0.10 & 160 & 0.58 \\
\hline
\end{tabular}




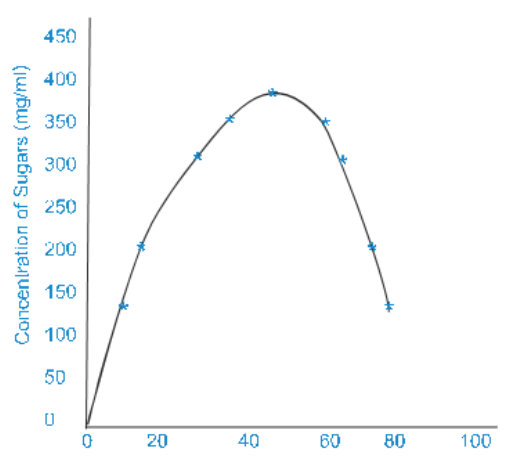

Fig3: Percentage of blended Malted Millet and Maize flour with the chaff

2.12 Determination of optimum blending ration of mallted millet and maize flour without the chaff

Maize flour obtained after removing the chaff was blended with malted millet in the following ratio to make up to $5 \mathrm{~g} .0 .5: 4.5,1.0: 4.0,1.5: 3.5,2.0: 3.0,2.5: 2.5,3.0: 2.0,3.5: 1.5,4.0: 1.0,4.5: 0.5$, the maize flour was gelatinized first in $100 \mathrm{ml} 0.05 \mathrm{ml}$ acetate buffer $\mathrm{Ph} 5.5$, allowed to cool to a temperature of $50^{\circ} \mathrm{C}$ before malted millet was added, the solutions were hydrolyzed at a temperature of $50^{\circ} \mathrm{C}$ using a thermostat water bath for 2 hours. Samples were withdrawn, centrifuged and assayed for reducing sugar by Nelson method using a colorimeter with max 520nm.

\section{Table 9:}

\begin{tabular}{|c|c|c|c|c|c|}
\hline S/No & $\begin{array}{c}\text { weight of maize } \\
\text { flower }(\mathrm{g})\end{array}$ & $\begin{array}{c}\text { weight of malted } \\
\text { millet }(\mathrm{g})\end{array}$ & $\begin{array}{c}\text { absorbance at } \\
520 \mathrm{~nm}\end{array}$ & $\begin{array}{c}\text { concentration } \\
(\mathrm{mg} / \mathrm{ml})\end{array}$ & $\begin{array}{c}\% \\
\text { hydrolyzed }\end{array}$ \\
\hline 1 & 0.5 & 4.5 & 0.06 & 80 & 0.29 \\
\hline 2 & 1.0 & 4.0 & 0.07 & 100 & 0.36 \\
\hline 3 & 1.5 & 3.5 & 0.08 & 120 & 0.43 \\
\hline 4 & 2.0 & 3.0 & 0.10 & 160 & 0.58 \\
\hline 5 & 2.5 & 2.5 & 0.14 & 140 & 0.86 \\
\hline 6 & 3.0 & 2.0 & 0.16 & 280 & 1.01 \\
\hline 7 & 3.5 & 1.5 & 0.13 & 220 & 0.79 \\
\hline 8 & 4.0 & 1.0 & 0.10 & 160 & 0.58 \\
\hline 9 & 4.5 & 0.5 & 0.07 & 100 & 0.36 \\
\hline
\end{tabular}

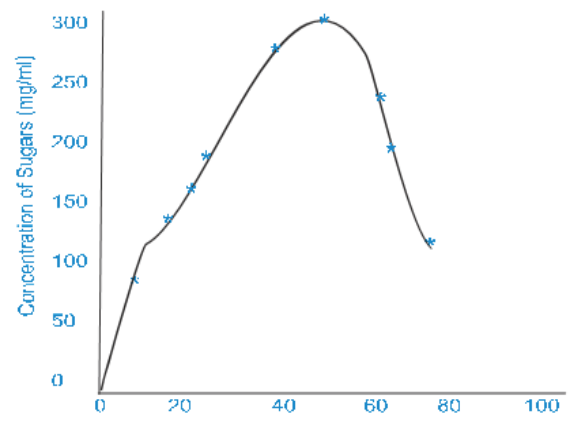

Fig. 4: Percentage of blended malted millet and maize flour without chaff 


\section{Discussion}

The result of the water uptake of the millet shows that there was rapid absorption of water at the initial steeping time but shows no significant change at 96 hours. This shows that, at 96 hours there is maximum Saturation of water by the seeds.

Results for the hydrolysis of malted millet for various hours (24-120) for temperatures between $30^{\circ} \mathrm{C}-80^{\circ} \mathrm{C}$ shows that amylase activity was higher at 96 hours of malting time. The temperatures at which the amylase functions best was found to be $50^{\circ} \mathrm{c}$. At higher temperature, there was decrease in the activity of the amylase. This could be due to the denaturation of the enzymes.

In table 1 , the ash content of the millet grains was determined to be $3.26 \% \pm 0.03$. This indicates a high mineral content in the millet grain.

Table 2 shows that the moisture content of the millet is $11.37 \% \pm 0.03$. The moisture content of Cereals usually depends on factors such as harvesting time as well as storage conditions. Adequate moderation of these conditions is needed to prevent detoriation due to high moisture content especially insect attack and fungal growth. However, moisture content of $10-12 \%$ is reported to be safe for grains intended to be stored for a long period of time.

The Crude fat content as shown in table 3 was determined to be $1.3 \% \pm 0.2$. generally, the total lipid (fat) content of cereals is about $5 \%$ of the dry grains. Though fats are useful nutritionally, they can constitute a problem in the brewing industries. This is because the degradation of fatly acid may give rise flavor defect in bear and milk drinks.

Table 4 shows the Crude protein of the millet to be $13.37 \% \pm 0.5$. In general, lower values of protein content is associated with cereals with higher carbohydrate content and vice-versa. Such cereals with higher carbohydrate content are said to produce extract which is rich in malt.

The carbohydrate content of the millet was determined to be $71.46 \%+0.08$. The reducing sugar content was found to be $35.08 \%+0.80$ while the hydrolysable sugar was determined to be $54.29 \%+0.70$. The lower values suggest that the use of acid hydrolysis could have resulted in the conversion of some carbohydrates to furans and pyrans.

Tables 7, 8 and 9 show the blending ratio of millet with gelatinized rice flour, maize flour with the chaff and maize flour without the chaff respectively. The values are $60 \%, 50 \%$ and $60 \%$ respectively. The decrease of $10 \%$ of reducing sugar production of the gelatinized maize with the chaff compared to the one without the chaff could be due to the fact that chaff of the seeds contain some lignified materials such as proteins fats and fibre, which are found in the outer seed coat of the grains and could constitute hindrance to enzyme activity.

Table 6 shows the presence of metals in the proso millet. Absence of lead metal (Pb) is an indication of the safety of consumption of the grain.

\section{Conclusion}

This research work shows that. Proso millet (panicum millaceum) is rich in protein, carbohydrate and also contains some important minerals such as calcium, Potassium, magnesium and I ron hence it is a good source of food and as an adjunct in the brewing industry.

\section{References}

Aisien, A. O. (1982) Enzymes modification of sorghum endosperm during seedling growth and malting, Journal of science food and agriculture. Vol 33: 745-759.

Benz. C. and Brue .F. 92001) Maize Origin, domestication and development: oxford encyclopedia of meso-American Culturs Vol 2 147-150, New York Oxford University.

Chris I.A. (2010) Laboratory Organic chemistry techniques qualitative analysis, organic preparations and spectroscopy. Maybinso publishers new Jersey USA 208-216. 
Crowford G.W and Shen C. (1998) The origin of rice Agriculture recent progress in east Asia. A Journal of antiquity Vol 72: 258-866.

Dashak, D.A. and Nwanegbo, V. (2002). Chemical composition of the seeds and calyxes of (Hibiscus Sabdariffa) grown in Jos North local government are of plateau state. Journal of natural sciences Vol 5:32-341.

Dashak A.D, Alabi O.A and Osadebe, J. (2004) An evaluation of the chemical composition and malting properties of finger millet. A journal of science and technology research $\mathrm{Vol} 3$, number 4

Food and nutrition Board (2005) Dietary intake for energy, carbohydrate, fibre, fatty acids cholesterol, proteins and amino acids, Washington DC USA, the national academic press 769-776.

Gabo L.E. (1994) Hydrolysis of maize grits blended with malted barley, the effect of metal ions on the hydrolysis. MSC thesis Department of Chemistry, University of J os.

Hands- Dieter B Werners G, and Peter S. (2004) food Chemistry $3^{\text {rd }}$ Springer edition 318-323.

Odabe C.K (2006) Hydrolysis of malted millet (Pennisetum Typhoides) blended with cassava flour, undergraduate thesis department of Chemistry University of J os.

Shambe T, Voncir N. and Gambo, E (1989) Enzyme and acid hydrolysis of malted cereals Journal of institute of brewing. Vol 77:Page 105-109.

Steiner, E. Gastl, M. and Becker, T. 92011). Protein changes during malting and brewing with focus on haze and foam formation: a review of European food research technology. Vol. 332 No. 2: 191-204. 